\title{
'Lucy' jilted?
}

\section{from M.H. Day}

WHAT'S a girl to do if her date lets her down? This question often has to be answered by girls who have waited in vain - but the question of interest here is has 'Lucy' (or to be more precise her slightly older 'relations') waited 3.3 or $\mathbf{3 . 6}$ million years before her date with Don Johanson, Yves Coppens and Maurice Taieb? These three, the leaders of the French/American expedition to the Hadar region of Ethiopia, have been responsible for the recovery of the early hominid material, known collectively as Australopithecus afarensis, from deposits that were originally said to range in age from 2.6 to 3.1 million years before the present. The famous Lucy is said to be part of that species, as are Mary Leakey's earlier Laetoli hominids from Tanzania'. Earlier this year, however, it was suggested that the dates of the basalts from the Hadar series had been underestimated by as much as $300,000-600,000$ years, bringing the earliest date of the Hadar site much closer to that of Laetoli, the site from which the A. afarensis type specimen was chosen ${ }^{2}$, this species being regarded by some as representing the common ancestor of the hominid stem.

An article ${ }^{3}$ in this issue of Nature (p.631) now questions this revision of the lower end of the temporal range of the Hadar hominids on grounds of stratigraphical corrclation between the Hadar Formation and sites in the Lake Turkana Basin, together with faunal studies that may be consistent with the younger rather than the older age for the bottom of the Hadar sequence. F.H. Brown reports the results of microprobe and X-ray fluorescence analysis of a group of volcanic tuffs from the Koobi Fora Formation (Tulu Bor), the Shungura Formation (Tuff B) and the Usno Formation (Tuff U-10). All these air fall tuffs are the result of volcanic eruptions and all are found in the Lake Turkana Basin of northern Kenya and southern Ethiopia. Further north in Ethiopia, the Sidi Hakoma Tuff has also been sampled from the Hadar site and added to the comparisons. The microprobe analyses of major and minor elements and the X-ray fluorescence analyses of minor and trace elements show remarkable correspondence in all of the tuffs examined and lead to the view that all were the result of broadly contemporancous events and thus may indicate isochronous lithostratigraphical horizons. This is said to producc a 'direct lithostratigraphical tie' between the Hadar Formation and the Lake Turkana region which can help to date the fossil faunas of the two areas,

M.H. Day is Professor at the Department of Anatomy, St Thomas's Hospital Medical School, L ambeth Palace Rd, London SEI 7EH. including the hominids.

The palaeomagnetic evidence shows that the three tuffs from the Lake Turkana basin are all of normal polarity and they are thought to lie in the Gauss Normal Epoch, having therefore an age of between 3.17 and 3.42 million years. The Sidi Hakoma Tuff also has a normal polarity. The two reversed zones above the Sidi Hakoma Tuff and their equivalents in the Shungura and Usno Formations have been regarded as the Mammoth and Kaena Events.

Potassium/argon (K/Ar) and fission track dates from the Hadar Formation are said to be consistent with those identifications with one interesting exception, the 3.6 Myr date for the Type B sample of the Kadada Moumou Basalt $(\mathrm{KMB})^{2}$. The date for this layer has been revised by Brown ${ }^{3}$ to $3.12 \mathrm{Myr}$ by applying a 3.5 per cent upward 'correction' to the 3.01 Myr date for the original Type A sample of the KMB, so that the reversed polarity of the KMB layer can sit conveniently in the Mammoth Event rather than be attributed to the underlying Gilbert reversal as it would be at 3.6 Myr. In the Lake Turkana Basin the palaeomagnetic identifications also apparently accord with the $\mathrm{K} / \mathrm{Ar}$ dates on the tuffs, with the exception of the date of Tuff B10 of the Shungura Formation which is said to be 'too old' at 3.75 Myr. This tuff is one of the uppermost units of the Shungura Formation and lies just below Unit B10, which produced most of the fauna from Member B referred to in a second paper ${ }^{4}$ published in this issue of Nature (p.633) that deals with the age of the Hadar Formation.

In these days of 'high-tech' science, there is something delightfully anachronistic about consulting an assemblage of fossil bones to support or disprove a numerical age produced by radiometric means. This was exactly what happened at Koobi Fora, however, where it took the 'pig clock' 5.6 to sort out the correct date for the KBS Tuff. Biostratigraphy, therefore, still has an important part to play in geochronology since its cumulative effect may also be enhanced by comparisons from several adjacent sites. In the paper by Boaz, Howell and McCrossin (p.633), two largemammal faunal lists, one from the Usno Formation (Lower B) and the other from Shungura (B10), have been compared with the Hadar assemblage and with each other by means of faunal similarity coefficients.

The Usno and Shungura comparative assemblages are given 'best-fit' $\mathrm{K} / \mathrm{Ar}$ and palaeomagnetic dates of 2.92 and $3.15 \mathrm{Myr}$ respectively and thus a time difference of about $0.2 \mathrm{Myr}$. The results show firstly that the Usno and Shungura assemblages are nearer to each other than either is to Hadar and secondly that by any test the Hadar and Usno faunas are closer than the Hadar and Shungura B10 faunas, suggesting that the Hadar fauna is closer to the older of the two dates. Unfortunately, sites such as Laetoli, Kanapoi, Mursi and Ekora, with a range of 3.2-4.0 Myr, cannot be compared with Hadar at present since their inventories are not complete. The faunal evidence, as far as it goes, therefore, seems to be consistent with the date for the Hadar site put forward by Brown, yet a pre-Usno date for Hadar is prudently not rejected. It seems that the correlative stratigraphical and faunal case for a younger lower limit for the Hadar site is interesting but not compelling.

What, then, would be the significance of this proposed revision (or perhaps reversion is a more appropriate word) of the dating of the Hadar site for hominid evolution? All seem agreed that the bulk of the Hadar hominids are older than 2.88 Myr. The lower limit of the range at Hadar is either 3.12 or $>3.6 \mathrm{Myr}$, a difference of 400,000 years or more with a possible span of 240,000-720,000 years at this site. This means that the Hadar sample of hominids is drawn from either a quarter or nearly three quarters of a million years; this must colour the views of those who would tackle the question of whether the Hadar sample is homogeneous and monospecific. Indeed, in relation to the Laetoli site, a gap of 370,000 years has re-opened in the evolutionary history of $A$. afarensis.

As well as the correctness of including the Laetoli hominid material in the same specific category as that of the Hadar sample, the question of the age of the Makapansgat site in the Republic of South Africa now begins to become relevant. A younger date for Hadar, if proven, coupled with an older date for Makapansgat ${ }^{7.8}$, could make it uncertain that Makapansgat Australopithecus africanus is more recent than Hadar Australopithecus afarensis. Laetoli is, of course, still older than either site; but if the specific unity of the Hadar A. afarensis sample or the inclusion of the Laetoli hominids in that sample is shown to be incorrect, then $A$. afarensis could be a stem form in name alone. The folly of selecting a type specimen both geographically and temporally separated from the largest and best fossil sample would then be exposed once more.

To let a girl down on her date is bad enough, but to get her name wrong when you do arrive would be intolerable!

\footnotetext{
Johanson, D.C., W'hite. T.D. \& Coppens, Y. Kirtlandie 28, 1 (1978)

2. Walter, R.C. \& Aronson, J.L.. Narure 296, 122 (1982).

Brown, F.H. Nature 299, 631 (1982).

4. BoaL, N.T., Howell, H.C. \& MiCrossin, M.1.. Nature 299, 633 (1982).

5. Cookc, H.B.S. in Earliest Man and Environment in the Lake Rudolf Basin (eds Coppens, Y., Howell, C., Isaac, G. L. \& L Lakey, R.E.F.) 251 (1976)

6. Harris, J.M. \& Whitc T.D. Trans. Am. phil. Soc. 69 1 (1979)

7. Vrba, E.S. in Ier Congrès International de Paléontologie Humaine, Nice, Prétirage, 707 (1982).

8. McFadden, P.I.., Brock, A. \& Partridge, T.C. Earth \& planel. Sci. Lett. 44, 373 (1972).
}

\section{CORRIGENDUM}

In the News and Views article 'Human monoclonal antibodies' (Nature 300, 316; 1982) D. Crawford's affiliation was given as the Imperial Cancer Research Fund Laboratories, I.ondon. She is in fact at the Department of Hacmatology, University Collcge I.ondon. 